\title{
EFFECTIVENESS OF BLENDED LEARNING IN LEARNING BIOLOGICAL SCIENCE AT STANDARD XI
}

Dr. D. Sumathi, (Author) Assistant Professor,

School of Education, Tamil Nadu Open University, Chennai- 600015

ORCID:

Email: sumathidesinguraj@gmail.com

Mrs. Shyla Gnanam Ebenezer, (Co-author) Ph.D. Research Scholar, School of Education, Tamil Nadu Open University, Chennai- 600015 ORCID:

Email: Shylatony5@gmail.com

Electronic version

URL: http://www.researchinspiration.com

DOI: https://doi.org/10.53724/inspiration/v6n2.02

ISSN: 2455-443X

Vol. 6, Issue-II, March 2021

Page No. 01- 07

Publisher

Welfare Universe

Electronic reference/Article is to be Cited:

Dr. D. Sumathi, \& Mrs. Shyla Gnanam Ebenezer, (2021) Effectiveness of Blended Learning In

Learning Biological Science At Standard XI. Research Inspiration: An International Multidisciplinary eJournal, ISSN 2456-443X, 6(II), 01-07. https://doi.org/10.53724/inspiration/v6n2.02

CResearch Inspiration: An International Multidisciplinary e-Journal 2021. This Open Access article is published under a Creative Commons Attribution Non-Commercial 4.0 International License https://creativecommons.org/licenses/by-nc/4.0/, which permits non-commercial reuse, distribution, and reproduction in any medium, provided the original work is properly cited. For citation use the DOI. For commercial re-use, please contact editor email:- publish1257@ gmail.com By accessing the work you hereby accept the Terms. Non-commercial uses of the work are permitted without any further permission from Research Inspiration: An International Multidisciplinary eJournal provided the work is properly attributed.

This work is licensed under a Creative Commons Attribution-NonCommercial 4.0 International License. 


\section{EFFECTIVENESS OF BLENDED LEARNING IN LEARNING BIOLOGICAL SCIENCE AT STANDARD XI}

Dr. D. Sumathi, (Author) Assistant Professor,

School of Education, Tamil Nadu Open University, Chennai- 600015

ORCID:

Email: sumathidesinguraj@gmail.com

Mrs. Shyla Gnanam Ebenezer, (Co-author) Ph.D. Research Scholar, School of Education, Tamil Nadu Open University, Chennai- 600015 ORCID:

Email: Shylatony5@gmail.com

\section{Abstract}

The major purpose of the study was to explore the impact of blended learning on the achievements of students. The study was experimental type. Equivalent group study design was used. The collected data of both groups were analysed and interpreted using mean, standard deviation and t-test, and conclusions were drawn. The results of the study were in the favour of blended learning approach, therefore, it is suggested that this approach should be widely used in conventional classroom at various levels of education.

Keywords: Blended Learning- It combines the best of both the usage of internet resources and the faceto-face classroom experience, Effectiveness- The term "effectiveness" refers here to the extent Blended learning produced better results in the terms of the scores of students in achievement tests, Biological Science- The biology text book of standard XI.

\section{Introduction}

E-learning has emerged as a model of learning due to the scientific and technological changes which the world is currently experiencing. As a result, the traditional methods are relatively unable to cope with these changes. Despite the advantage soft E-learning, it has some short comings represented in the lack of face-to-face interaction which necessitates the availability of a new model combining some characteristics of both traditional learning and ELearning which can overcome the disadvantages of both kinds of learning. Thus, a more advanced model, Blended Learning (BL) has emerged (Khaled Nahs Raqas Alotaibi, 2013).

Blended (hybrid) learning is defined as a coherent design approach that integrates the strength soft faceto-face and online learning to address worthwhile educational goals (Farahnaz ovahedzadeh2012). Blended learning goes beyond barrier soft time, location, and culture and has created many enhanced opportunities for learners and instructors. (Nikolaos Vernadakiset al 2012) We must take some serious steps to bridge the gap and schools can best prepare the students for their future careers by adopting blended learning model to help students develop the essential 21st century skills. (Saloom Aslam 2015) E-Learning is considered as an excellent substitute for delivering educational services for learners everywhere and anywhere, as it does not have the normal obstacles of traditional education inside 
classrooms and labs, therefore, it complements the existing teaching styles (Isman et al, 2012). Most schools in developed or developing countries try to adapt their education systems to Communication technologies .Therefore, educational technologies are used effectively by instructors in educational settings and will continue to be used in future as well (Umit Yapici and Hasan Akbayin, 2012)

\section{Need And Significance Of The Study}

Learners of standard XI face the problems in learning biological science by adopting conventional methods of learning. Student's scoreless marks in achievement tests due to monotony of conventional methods of teaching biological science. Hence the researcher endeavours to find an innovative method for eliminating the problems of the learners and proposes to find out the effectiveness of Blended learning in learning biological science in this study.

\section{STATEMENT OF THE PROBLEM:}

Students have problems in scoring more marks in Biological Science at standard XI.

\section{OPERATIONAL DEFINITIONS:}

Effectiveness- The term "effectiveness" refers here to the extent Blended learning produced better results in the terms of the scores of students in achievement tests.

Blended Learning- It combines the best of both the usage of internet resources and the face-to-face classroom experience.

Biological Science- The biology text book of standard XI.

\section{Objectives}

1. To find out whether there is any significant difference in achievement mean score between the pre-test of control group and posttest of control group.

2. To find out whether there is any significant difference in achievement mean score between the pre-test of experimental group and posttest of experimental group.

3. To find out whether there is any significant difference in achievement mean score between the posttest of control group and posttest of experimental group.

4. To find out whether there is any significant difference in achievement mean score between the posttest of experimental group and posttest of control group.

5. To find out the impact of Blended Learning on the Biological Science Achievement scores at standard XI.

\section{Hypotheses}

The researcher has framed the following hypotheses:

1. There is no significant difference in achievement mean score between the pre-test of control group and posttest of control group.

2. There is no significant difference in achievement mean score between the pre-test of experimental group and posttest of experimental group.

3. There is no significant difference in achievement mean score between the post- test of control group and posttest of experimental group.

4. There is no significant difference in achievement mean score between the post-test of experimental group and posttest of control group.

5. Blended Learning will be more effective on the Biological Science Achievement scores at standard XI than the conventional method. 


\section{VARIABLES:}

INDEPENDENT VARIABLE: The traditional method of teaching and the blended learning.

DEPENDANT VARIABLES: Achievement Scores of the students.

METHODOLOGY: Parallel group Experimental method (control group and experimental group) will be adopted for the study.

POPULATION: XI standard students studying in Tirupur will be considered as population of the study.

SAMPLING: Fifty students studying in Standard XI at Govt. Higher Secondary School, Tirupur (25 control group + 25 Experimental group =50) will be selected as sample for the study.

TOOL: Researcher's self-made achievement test will be considered as a tool for the study.

STATISTICAL TECHNIQUE: Mean, Median and t test was done to analyse the data.

PROCEDURE: Pre- test_ treatment_ post- test was considered as procedure of the study. Conventional teaching method was adopted for Controlled group. Blended learning will be adopted as treatment to the Experimental group.

ANALYSIS AND INTERPRETATION OF DATA:

DISTRIBUTION OF PERFORMANCE SCORES OF CONTROL GROUP (CONVENTIONAL METHOD) STUDENTS IN PRETEST: Pre-test was administered to 30 control group students of standard XI. The distribution of performance scores of the control group is presented in the following table-1.

TABLE-1

General performance scores of control group students of standard XI in pre-test

\begin{tabular}{|c|c|c|}
\hline Class interval (scores) & Frequency & Percentage \\
\hline $1-5$ & - & - \\
\hline $6-10$ & 18 & 60.00 \\
\hline $11-15$ & 5 & 16.70 \\
\hline $16-20$ & 7 & 23.30 \\
\hline $21-25$ & - & - \\
\hline Total & 30 & 100 \\
\hline
\end{tabular}

\section{DISTRIBUTION OF PERFORMANCE SCORES OF EXPERIMENTAL GROUP (BLENDED}

LEARNING METHOD) STUDENTS IN PRE TEST: Pre-test was administered to 30 control group students of standard XI. The distribution of performance scores of the experimental group is presented in the following table -2 .

TABLE - 2

General performance scores of experimental group students of standard XI in pre-test

\begin{tabular}{|c|c|c|}
\hline Class interval (scores) & Frequency & Percentage \\
\hline $1-5$ & - & - \\
\hline $6-10$ & 15 & 50.00 \\
\hline $11-15$ & 7 & 23.30 \\
\hline $16-20$ & 8 & 26.70 \\
\hline $21-25$ & - & - \\
\hline Total & 30 & 100 \\
\hline
\end{tabular}

DISTRIBUTION OF PERFORMANCE SCORES OF CONTROL GROUP (CONVENTIONAL METHOD) STUDENTS IN POST TEST: Post-test was administered to 30 control group students of standard XI. The distribution of performance scores of the control group is presented in the following 
table-.3.

TABLE - 3

General performance scores of control group students of standard XI in post-test

\begin{tabular}{|c|c|c|}
\hline Class interval(scores) & Frequency & Percentage \\
\hline $1-5$ & - & - \\
\hline $6-10$ & 15 & 50.00 \\
\hline $11-15$ & 7 & 23.30 \\
\hline $16-20$ & 8 & 26.70 \\
\hline $21-25$ & - & - \\
\hline Total & 30 & 100 \\
\hline
\end{tabular}

\section{DISTRIBUTION OF PERFORMANCE SCORES OF EXPERIMENTAL GROUP (BLENDED}

LEARNING METHOD) STUDENTS IN POST TEST: Post-test was administered to 30 experimental group students of standard XI. The distribution of performance scores of the experimental group is presented in the following table-4.

TABLE -4

General performance scores of experimental group students of standard XI in post-test

\begin{tabular}{|c|c|c|}
\hline Class interval(scores) & Frequency & Percentage \\
\hline $1-5$ & - & - \\
\hline $6-10$ & 10 & 33.30 \\
\hline $11-15$ & 6 & 20.00 \\
\hline $16-20$ & 8 & 26.70 \\
\hline $21-25$ & 6 & 20.00 \\
\hline Total & 30 & 100 \\
\hline
\end{tabular}

\section{TESTING OF HYPOTHESIS}

The students had problems in learning biology through conventional method at Standard XI.

Table -3 indicates that most $50 \%$ of the students of control group scored between $6-10$. Table-4 indicates that only $33.33 \%$ of the experimental group scored between 6-10.

From the percentage score in table 3 and table 4 it is clear that the students of control group had problem in learning biology through the conventional method.

Table-5

Means of post-test scores of students

\begin{tabular}{|c|c|c|}
\hline Groups & $\mathrm{N}$ & Mean \\
\hline Control & 30 & 12.00 \\
\hline Experimental & 30 & 14.67 \\
\hline
\end{tabular}

\section{INFERENTIAL ANALYSIS}

Inferential analysis consists of using probability to make the decision about the population on the basis of sample observation. The main objective of this study is to find out the effectiveness of Blended Learning Method in enhancing achievement in biological Science at Standard XI. This section describes the inferential analysis of mean achievement scores.

TESTING OF NULL HYPOTHESIS- 1: There is no significant difference between the pre-test and post-test mean score of control group.

TABLE -6

Difference between pre-test and post-test mean score of control group

\begin{tabular}{|l|l|l|l|l|l|l|}
\hline Groups & $\mathbf{N}$ & Mean & SD & df & 't' value & Significance level- 0.05 \\
\hline $\begin{array}{l}\text { Control } \\
\text { pre-test }\end{array}$ & 30 & 11.17 & 4.17 & 58 & 0.67 & Not significant \\
\hline
\end{tabular}


The above table shows the obtained ' $t$ ' value 0.67 is statistically not significant because it is lesser than the critical value 1.96 for $58 \mathrm{df} 0.05$ level of significance.

Therefore the null hypothesis is accepted. From this it can be concluded that there is no significant difference between the mean gain score of pre and posttest of control group.

TESTING OF HYPOTHESIS-2: There is no significant difference between the pre-test and the posttest mean score of experimental group.

TABLE -7

Difference between pre-test and post-test mean score of experimental group

\begin{tabular}{|c|c|c|c|c|c|c|}
\hline Groups & $\mathbf{N}$ & Mean & SD & $\mathbf{d} \mathbf{f}$ & ' $t$ ' value & $\begin{array}{c}\text { Significance level } \\
0.05\end{array}$ \\
\hline $\begin{array}{c}\text { Experimental pre- } \\
\text { test }\end{array}$ & 30 & 11.83 & 3.95 & \multirow[b]{2}{*}{58} & \multirow[b]{2}{*}{2.25} & \multirow[b]{2}{*}{ Significant } \\
\hline $\begin{array}{l}\text { Experimental } \\
\text { post-test }\end{array}$ & 30 & 14.67 & 5.67 & & & \\
\hline
\end{tabular}

The above table shows the obtained ' $\mathrm{t}$ ' value 2.25 is statistically significant because it is greater than the critical value 1.96 for $58 \mathrm{~d}$ f 0.05 level of significance.

Therefore the null hypothesis is rejected. From this it can be concluded that there is significant difference between the mean gain score of pre and posttest of experimental group.

\section{TESTING OF NULL HYPOTHESIS -3:}

There is no significant difference between the pre-test mean score of control group and the pre-test mean score of experimental group.

Table: 08

\begin{tabular}{|c|c|c|c|c|c|c|}
\hline Groups & $\mathbf{N}$ & Mean & SD & df & 't' value & $\begin{array}{c}\text { Significance level } \\
\mathbf{0 . 0 5}\end{array}$ \\
\hline Control Pre-test & 30 & 11.17 & 4.17 & & & \\
\cline { 1 - 1 } $\begin{array}{c}\text { Experimental } \\
\text { Pre-test }\end{array}$ & 30 & 11.83 & 3.95 & 58 & 0.63 & Not significant \\
\hline
\end{tabular}

Difference between pre-test mean scores of control group and pre-test mean score of experimental group:

The above table shows the obtained $t$ value 0.63 is statistically not significant because it is lesser than the critical value 1.96 for $58 \mathrm{~d}$ f 0.05 level of significance.

Therefore the null hypothesis is accepted. From this it can be concluded that there is no significant difference between the mean gain score of pre-test of control group and pre-test of experimental group.

\section{TESTING OF NULL HYPOTHESIS-4:}

There is no significant difference between the post-test mean scores of control group and the post-test mean scores of experimental group.

TABLE -9

Difference between pre-test and post-test mean score of control group

\begin{tabular}{|c|c|c|c|c|c|c|}
\hline Groups & $\mathrm{N}$ & Mean & $\mathrm{SD}$ & $\mathrm{df}$ & ' $\mathrm{t}$ ' value & $\begin{array}{c}\text { Significance level } \\
0.05\end{array}$ \\
\hline $\begin{array}{c}\text { Control } \\
\text { post-test }\end{array}$ & 30 & 12.00 & 4.16 & & & Significant \\
\hline $\begin{array}{c}\text { Experimental } \\
\text { post-test }\end{array}$ & 30 & 14.67 & 5.67 & 58 & 2.08 & \multirow{2}{*}{5} \\
\hline
\end{tabular}

The above table shows the obtained ' $\mathrm{t}$ ' value 2.08 is statistically significant because it is greater than the 
critical value 1.96 for $58 \mathrm{~d}$ f 0.05 level of significance.

Therefore the null hypothesis is rejected. From this it can be concluded that there is significant difference between the mean gain score of post-test of control group by conventional method and post-test of experimental group by blended learning method.

\section{Alternate Hypothesis:}

Blended Learning method is more effective than conventional method. Table -5 indicates that the mean value of the control group is 12 and that of the experimental group is 14.67. Hence the students of experimental group have scored more marks through Blended Learning Method than control group in their achievement in Biological Science at Standard IX. Thus it shows that the Blended Learning method is more effective than conventional method in enhancing achievement in Biological Science at Standard XI.

\section{Findings of the study}

$>$ The students of Standard XI have learning problems in learning Biological Science in Chinnasamyammal Corporation Hr. Sec. School, Tirupur.

$>$ There is no significant difference between the pre-test and post-test mean score of control group.

$>$ There is a significant difference between the mean score of pre-test and post-test mean score of experimental group.

$>$ There is no significant difference between the pre-test mean scores of control group and the experimental group.

$>$ There is a significant difference between the post-test mean scores of control group and experimental group.

\section{Conclusion of the study:}

Research in any area is only a humble beginning to explore the cause and effect relationships. Blended learning method is fairly a new method and its full potential is yet to be realized in the field of education. In this way this investigation is a contribution to education.

\section{References:}

1. Umit Yapici and Hasan Akbayin (2012): The effectiveness of blended learning model on high school students' biology achievement and on their attitude towards the internet. TOJET: The Turkish Online Journal of Educational Technology April 2012, volume 11 Issue 2.

2. Isman, Aytekin, Abanmy, Fahad Abdul-Aziz Hussein, Hisham Barakat (2012): Using blended learning in developing student teachers teaching skills. TOJET: The Turkish Online Journal of Educational Technology - October 2012, volume 11 Issue 4.

3. Farahnaz Movahedzadeh (2012): Improving Student Success through Hybrid Mode of Delivery in Non science Major Biology Classes. Education 2012, 2(7): 333-339 DOI: 10.5923/j.edu.20120207.17

4. Khaled Nahs Raqas Alotaibi (2013): The Effect of Blended Learning on Developing Critical Thinking Skills. Education Journal. Vol. 2, No. 4, 2013, pp. 176-185. doi: 10.11648/j.edu.20130204.21, Published online Aug.10, 2013, http://www.sciencepublishinggroup.com/j/edu

5. Saloom Aslam (2015): A Comparative Study of Blended Learning versus Traditional Teaching in Middle School Science. Article- International conference -The future of education Nikolaos Vernadakis, Maria Giannousi, Vassiliki Derri, Maria Michalopoulos.

6. Efthimis Kioumourtzoglou (2012): The impact of blended and traditional instruction in students' performance, INSODE 2011, Procedia Technology 1 (2012) 439 - 443. Available online at www.sciencedirect.com. 